\title{
Role of a Miracle Tree (Moringa oleifera) in Healthcare
}

\author{
Nisha Rani Yadav¹, Meena Jain², Ankur Sharma³ ${ }^{3}$ Aparna Aggarwal", \\ Meetika Pahuja ${ }^{5}$, Anoushka Mehta ${ }^{6}$, Advika Rawal7, Vishal Jain ${ }^{8}$ \\ 1,2,3,6,7 Department of Public Health Dentistry, Manav Rachna Dental College, FDS, MRIIRS, Faridabad, \\ India. ${ }^{4}$ Department of Oral Medicine \& Radiology, Jazan, Kingdom of Saudi Arabia. ${ }^{5}$ Department of \\ Public Health Dentistry, Kalka Dental College, Meerut, Maharashtra, India. ${ }^{8}$ Department of \\ Paediatric Dentistry, Manav Rachna Dental College, FDS, MRIIRS, Faridabad, India.
}

\section{ABSTRACT}

\section{BACKGROUND}

Moringa oleifera Lam is a plant found in Himalayan foothills. A large corpus of literature exists about moringa and its medicinal values. Various medicinal and health properties of moringa make it a part of various phytomedicinal preparation. It is used as a part of routine diet and has anti-fibrotic, anti-inflammatory, antimicrobial, antioxidant, anti-hyperglycaemic and anti-tumour properties. It is also used in production of seed oil, fodder and medicine. It is highly useful as a nutritional supplement, in the management of various diseases and in the management of public health problems. Moringa oleifera Lam is an important part of South Indian diet. Its antibacterial properties were found to be effective against E. coli, Salmonella typhi and Shigella dysenteriae. Hence, it may be used as a low-cost material for water purifications in poor communities. This plant has significance in dental health due to its antimicrobial effect on bacteria present in dental plaque like Staphylococcus aureus and Streptococcus mutans. There has been limited research on efficacy and safety of various Moringa oleifera (MO) extracts and parts in oral healthcare. MO has found its applications in various aspects of public health. As a plant with high nutritional value and relatively low cost, it has been endorsed as a plant with immense potential as for use as nutrient supplement in the parts of the world with widespread malnutrition and nutritional deficiencies. Further research needs to be conducted in the field of pharmacological management and prevention of oral disease.

\section{KEY WORDS}

Antimicrobial, Dental Diseases, Moringa oleifera, Streptococcus mutans.
Corresponding Author:

Dr. Meena Jain,

Department of Public Health

Dentistry, Manav Rachna Dental

College, FDS, MRIIRS,

Faridabad, India.

E-mail:drmeenabansal@gmail.com

DOI: $10.14260 / j e m d s / 2021 / 338$

How to Cite This Article:

Yadav NR, Jain M, Sharma A, et al. Role of a miracle tree (Moringa oleifera) in healthcare. J Evolution Med Dent Sci 2021;10(21):1628-1632, 10.14260/jemds/2021/338

Submission 14-01-2021, Peer Review 26-03-2021, Acceptance 31-03-2021, Published 24-05-2021.

Copyright (c) 2021 Nisha Rani Yadav et al. This is an open access article distributed under Creative Commons Attribution License [Attribution 4.0 International (CC BY 4.0)] 


\section{BACKGROUND}

Moringa oleifera lam. is a medium size tree of family moringaceae distributed in tropical and sub-tropical regions of India (especially in the Himalayan foothills). ${ }^{1,2,3}$ It is distributed worldwide and often cultivated for its nutritional value and medicinal properties. Even though the tree best grows in a temperature range of $25-35 \mathrm{C}$, it can survive even high temperatures found in tropical countries. ${ }^{4}$ Owing to its nutritional value, various parts of moringa, especially, seeds, flowers and pods are widely used as a part of routine diet. ${ }^{5}$

Additionally, moringa is also used in production of seed oil, fodder and medicine. ${ }^{6}$ Its nutritional properties have been well recognised. Studies have found it to be a good source of various minerals such as potassium, calcium, iron etc.7,8,9 Moringa has also been found to be a good source of essential amino acids and various antioxidants. ${ }^{10}$ This makes it an important nutrient source, especially in areas of the world where malnutrition is common.

A large corpus of literature exists about moringa and its medicinal values. Various medicinal and health properties of moringa also make it a part of various phytomedicinal preparation. ${ }^{11,12}$ In addition to its nutritive value, it is also used as an anti-fibrotic, anti-inflammatory, antimicrobial, antioxidant, anti-hyperglycaemic and anti-tumour properties. ${ }^{13}$ Parts of the plant such as leaves, seed, stem, roots and flowers are used to prepare various medicinal and food products. ${ }^{14,15}$ Preparations of methanolic and aqueous extracts of different parts of the plant have been tested previously. These preparations are often used as herbal medicines for control and treatment of diseases and health-related conditions. ${ }^{16}$

Use of moringa in India is even more relevant as it is often cultivated and widely used as an ingredient of food and food products. Although it is widely consumed by people of the complete subcontinent, but it is especially considered as an important part of South Indian diet.

In spite of its various uses as a medicinal plant, use of moringa in dentistry is limited. Even though it has been used in a few toothpaste and mouth rinse preparations, research is still missing on implications of this plant and its extracts on dental and oral health. The purpose of the present research is exploring the use of Moringa oleifera Lam. and its extracts in pharmacological prevention, control and treatment of oral and dental diseases.

\section{MORINGA AS A MEDICINAL PLANT}

MO has been popular and extensively used as a medicinal plant since a long time. Due to its widespread medicinal use, it has often been called as 'miracle tree'.6,17 Different parts of MO are rich in different components which make them useful pharmacological agents. The Moringa seeds contain cytokines. Various cytokines have been extracted from MO seeds through aqueous extracts. ${ }^{18}$ Its bark is known to contain moringine and moringinine alkaloids. ${ }^{19}$ Apart from these alkaloids, various other chemicals are also extracted from the seeds of moringa which have medicinal properties. MO flowers contain nine amino acids along with sugars and alkaloids. ${ }^{20}$ Similarly, leaves of MO also contain chemicals with medicinal potential. Roots of MO have been used as rubefacient, carminative, anti- inflammatory and laxative. ${ }^{21}$ It has also been used in treatment of pains such as rheumatism and articular pains. ${ }^{22}$ Its stem has been used in ocular afflictions as well as splenomegaly treatment of ulcers. ${ }^{23}$ Leaves of MO have been used as home remedy for sores and headaches. Additionally, they have also been used in treatment of sore throat, piles and ear infections. moringa gum has been used for oral health and dental caries. With a wide variety of uses in health, MO is a plant with high potential for extraction of herbal medicines. ${ }^{24}$

\section{Moringa in the Treatment of Cancer}

Moringa oleifera Lam preparations have been used in multiple ways during treatment of cancers. Anticancer effect of moringa has been attributed to inhibition of cancer cell growth and proliferation due to three bioactive components - 4- $(\alpha-\mathrm{L}$ rhamnosyloxy) benzyl isothiocyanate, $\beta$-sitosterol-3-0- $\beta$-Dglucopyranoside, and nizimicin. ${ }^{25}$ Glucosinolates in moringa extracts have been found to be effective in induction of apoptosis of cancer cells. ${ }^{26}$ In some cases, these extracts have also acted to induce P53 tumour suppressor gene during cancer therapy. Anticancer properties have been observed in leaf and bark extracts of moringa, while the seed extract has not been proven to have an anti-proliferative effect on cancer cells. ${ }^{27,28}$

Therapeutic activities of Moringa oleifera have also been studied in cancer cachexia. MO leaf diet has shown improvement in ATPase activity in experimental animals, thereby, implying help in muscular degeneration during cancer cachexia. ${ }^{29}$ additionally, effect of MO has also been found as having antioxidant properties, thereby reducing oxidative stress during cancer cachexia. However, these properties have been proven in experimental animals, and human studies need to be undertaken before definitive evidence on efficacy is obtained for use of MO in cancer cachexia.

Studies have been conducted to demonstrate in vitro effects of MO extracts on various cancer cell lines. More importantly, affects have been studied in oesophageal cancer, hepatocellular carcinoma and colorectal cancer. Owing to effect of MO extracts on different cancer lines, it is important that effect of these extracts should also be studied on oral cancer cell lines.

\section{Antimicrobial Aspects of Moringa}

Antimicrobial activity of MO may be contributed to the essential oil fraction of the distillate from the plant sources. ${ }^{30}$ Antibacterial and antifungal activity has been demonstrated from MO extracts. Antibacterial effect has been mainly demonstrated against E. coli, S. aureus, K. pneumoniae, B. subtilis and $P$. aeruginosa. Broad spectrum activity of MO leaf extracts has been demonstrated against food-borne microorganisms. This activity mainly comes from MO leaf and seed extract. Ethanolic extracts of MO leaves have been found to be effective against E. coli, Enterobacter aerogenes, Pseudomonas aeruginosa, and Staph. aureus. Salmonella typhimurium and E. coli have been found to be affected by the seed chlorophyll extracts of MO. Isothiocyanates from MO are also effective against Helicobacter pylori, a microorganism that is often found in geographical regions of world where there is a lack of medical facilities and widespread poverty. The other 
similar microorganism against which MO extracts are effective is Vibrio cholera. Antimicrobial activity of MO extends to certain fungal species also. ${ }^{31}$

An important aspect of antimicrobial activity of MO is its anti-biofilm activity. ${ }^{32}$ This activity has been studied in vitro as well as in increasing shelf life of certain food products. Antioxidant activity of MO owing to the presence of flavonoids, keratinoid, ascorbic acid and phenolic compounds is useful in prevention of biofilm on food products. ${ }^{33,34}$

However, there has been no study on dental plaque biofilm and effects of MO extracts on its prevention and breakdown. Antimicrobial aspects of MO have been studied on oral hygiene and as a part of dentifrices, however, detailed studies and mechanism of action of MO on plaque formation has not been studied and may prove to be important part of future research.

\section{MORINGA IN PUBLIC HEALTH}

MO has found its applications in various aspects of public health. As a plant with high nutritional value and relatively low cost, it has been endorsed as a plant with immense potential as for use as nutrient supplement in the parts of the world with widespread malnutrition and nutritional deficiencies. In line with the nutrient properties, MO has been used as a food supplement, especially for treatment of malnutrition in children. Proteins make up about a quarter of its dry weight and mostly contain proteins. MO contains 19 amino acids that make it a good source of proteins. Further, animal studies have shown that moringa has significant hepato-protective activity as well as nephro-protective activity in animals on drugs like Gentamycin, acetaminophen, and rifampicin. ${ }^{35}$

MO seed powder and extract has been found useful in water purification. According to a study conducted in Ethiopia, seed powder as well as acetone extract have proven to be useful for reduction in water borne disease. It has been effective in reducing coliform count as well as improving $\mathrm{pH}$ of water. It was also effective in reducing turbidity of water. Its antibacterial properties were found to be effective against $E$. coli, Salmonella typhi and Shigella dysenteriae. Hence, it may be used as a low-cost material for water purifications in poor

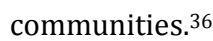

\section{IMPLICATIONS OF MORINGA IN DENTAL HEALTHCARE}

Studies on use of MO in oral care have been few and nonextensive. These studies broadly imply on antimicrobial properties of MO. These may further be applied towards reduction of cariogenic bacteria in oral environment. Staphylococcus aureus and Streptococcus mutans are the two bacteria where MO has been found to be effective. These two bacteria form important components of the plaque layer. ${ }^{37,38}$ Table 1 shows studies proving antimicrobial effect of MO in dental health.

MO is one of the herbs used by people of Dakshin Kannada for the maintenance of their oral hygiene. ${ }^{39} \mathrm{MO}$ is also known to remineralise enamel and dentin in patients having erosive and wasting diseases of teeth. ${ }^{40}$ Therefore, MO's effectiveness as antimicrobial agent for preventing oral disease is well validated. ${ }^{40,41,42,43}$ Similar to MO, honey and Quercus infectoria also have antimicrobial effect on Streptococcus mutans. ${ }^{44,45}$ So, medicinal plants are potential of antimicrobial compounds.

However, the research on use of MO in dental hygiene and dental care is limited, so future research needs to be conducted in this field.

\begin{tabular}{|c|c|c|c|c|c|}
\hline $\begin{array}{l}\text { Sl. } \\
\text { No. }\end{array}$ & Authors & Year & $\begin{array}{l}\text { Type of } \\
\text { Study }\end{array}$ & Study Objective & Dental Health Implications \\
\hline 1 & $\begin{array}{l}\text { Jose M, Bhagya B, } \\
\text { Shantaram M.41 }\end{array}$ & 2011 & $\begin{array}{l}\text { Descriptive } \\
\text { study }\end{array}$ & $\begin{array}{l}\text { To document the ethno-medicinal practices followed for oral } \\
\text { health and diseases by people of Dakshina Kannada (DK) } \\
\text { district, }\end{array}$ & $\begin{array}{c}32 \text { identified species belonging to } 29 \text { genera and } 20 \text { families, were } \\
\text { commonly used by the people of Dakshin Kannada region to maintain } \\
\text { oral health and hygiene and as remedy for dental diseases. MO was one } \\
\text { among them. }\end{array}$ \\
\hline 2 & $\begin{array}{l}\text { S Khalaf E A, Nagib } \\
\text { A M, Amin L E M, } \\
\text { Ibrahim F M M }{ }^{42}\end{array}$ & 2016 & $\begin{array}{l}\text { Intervention } \\
\text { study }\end{array}$ & $\begin{array}{l}\text { To determine the effect of renal insufficiency on patients' teeth } \\
\text { (enamel and dentin) and study biological effects of topical } \\
\text { application of moringa extract versus fluoride on extracted } \\
\text { teeth. }\end{array}$ & $\begin{array}{l}\text { Increase in calcium and phosphorus levels was statistically significant } \\
\text { with moringa as same as CPP-ACPF groups. Moringa oleifera has a } \\
\text { protective effect on enamel and dentin remineralisation that is similar } \\
\text { to CPP-ACPF paste in preventing erosion of enamel and dentin by } \\
\text { localising Ca and P at the tooth surface. }\end{array}$ \\
\hline 3 & $\begin{array}{c}\text { Rao P K, Rao D B, } \\
\text { kiran C, Nadh M R, } \\
\text { Madhavi Y, Rao T } \\
\text { R. } .^{33}\end{array}$ & 2011 & $\begin{array}{l}\text { Intervention } \\
\text { study }\end{array}$ & $\begin{array}{l}\text { To assess the antibacterial activity of isolated compounds from } \\
\text { M. oleifera against selected oral } \\
\text { bacteria }\end{array}$ & $\begin{array}{l}\text { All the isolated compounds from M. oleifera were active against } \\
\text { Streptococcus mutans (MTCC 497), Streptococcus } \\
\text { salivarius, Lactobacillus fermentum, Streptococcus anginosus, } \\
\text { Streptococcus gordonii, Lactobacillus acidophilus. }\end{array}$ \\
\hline 4 & $\begin{array}{c}\text { Alsaraf KM, Abd S T, } \\
\text { Husain S N }\end{array}$ & 2016 & $\begin{array}{l}\text { Intervention } \\
\text { study }\end{array}$ & $\begin{array}{l}\text { To assess the antibacterial and antifungal activities of aqueous } \\
\text { extracts of plant Moringa oleifera in comparison to } \\
\text { chlorohexidine gluconate and de-ionized water. }\end{array}$ & $\begin{array}{l}\text { The water extract of Moringa oleifera showed better antibacterial effect } \\
\text { than chlorhexidine on the tested organisms: Staphylococcus } \\
\text { aureus and streptococcus spp. } \\
\text { Maximum zone of inhibition was seen against S. aureus }\end{array}$ \\
\hline 5 & $\begin{array}{l}\text { Rostiny, Djulaeha E, } \\
\text { Hendrijantini N, } \\
\text { Pudijanto } \mathrm{A}^{45}\end{array}$ & 2016 & $\begin{array}{l}\text { Intervention } \\
\text { study }\end{array}$ & $\begin{array}{l}\text { To evaluate the effect of combined Moringa oleifera leaf extract } \\
\text { and demineralised freeze-dried bovine bone xenograft } \\
\text { (DFDBBX) towards the formation of osteoblasts and osteoclasts } \\
\text { in the tooth extraction sockets of Cavia cobaya }\end{array}$ & $\begin{array}{l}\text { Combination of Moringa oleifera leaf extract and DFDBBX at } 2 \% \\
\text { concentration can increase the number of osteoblasts and decrease } \\
\text { osteoclasts in the healing of tooth extraction sockets of Cavia cobaya }\end{array}$ \\
\hline 6 & $\begin{array}{l}\text { Elgamily H, Moussa } \\
\text { A, Elboraey A, El } \\
\text { Sayed A, Al } \\
\text { Moghazi, Abdalla } \\
\text { A }^{39}\end{array}$ & 2016 & $\begin{array}{l}\text { Intervention } \\
\text { study }\end{array}$ & $\begin{array}{l}\text { To assess the antibacterial and antifungal potentials of different } \\
\text { parts of Moringa oleifera plant using different extraction } \\
\text { methods }\end{array}$ & $\begin{array}{l}\text { Ethanol extracts as well as leaf extracts demonstrated the highest } \\
\text { significant mean inhibition zone values }(\mathrm{P} \leq 0.05) \text { against } \\
\text { Staphylococcus aureus and Streptococcus mutans growth }\end{array}$ \\
\hline 7 & $\begin{array}{l}\text { Carranza J B, Molina } \\
\text { P G L, Ortanez J J, } \\
\text { Taclan L B, Mergal V } \\
\quad \text { C, Yllano } 0^{40}\end{array}$ & 2017 & $\begin{array}{l}\text { Intervention } \\
\text { study }\end{array}$ & $\begin{array}{l}\text { To identify the secondary compounds of three varieties of } \\
\text { moringa oleifera Lam. extracts namely; Native, Chinese, and } \\
\text { Yard Long malunggay using phytochemical analysis. }\end{array}$ & $\begin{array}{l}\text { The extracts of moringa varieties contain flavonoids, alkaloids and } \\
\text { tannins that are known to have antimicrobial and anti-inflammatory } \\
\text { properties; thus, these have potential natural components in the } \\
\text { manufacture of toothpastes }\end{array}$ \\
\hline \multicolumn{6}{|c|}{ Table 1. Dental Health Implications of Moringa oleifera } \\
\hline
\end{tabular}




\section{CONCLUSIONS}

Moringa oleifera Lam is a widely grown plant with multiple uses in healthcare. Its pharmacological benefits are well documented and applied. It is highly useful as a nutritional supplement, in the management of various diseases and management of public health problems. However, its use in prevention and management of dental disease is limited. There has been limited research on efficacy and safety of various MO extracts and parts in oral healthcare. Future research in this field may hold promising results in pharmacological management and prevention of oral disease.

Financial or other competing interests: None.

Disclosure forms provided by the authors are available with the full text of this article at jemds.com.

\section{REFERENCES}

[1] Ramachandran C, Peter KV, Gopalakrishnan PK. Drumstick (Moringa oleifera): a multipurpose Indian vegetable. Economic Botany 1980;34(3):276-83.

[2] Kumssa DB, Joy EJ, Young SD, et al. Variation in the mineral element concentration of Moringa oleifera Lam. and M. stenopetala (Bak. f.) Cuf.: role in human nutrition. PLoS One 2017;12(4):e0175503.

[3] Jain S, Vaidya A, Shah K, et al. Anti-sickling Herbs. Plant and Human Health 2019;3:255-83.

[4] Singh VP, Arulanantham A, Parisipogula V, et al. Moringa olifera: nutrient dense food source and World's most useful plant to ensure nutritional security, good health and eradication of malnutrition. European Journal of Nutrition \& Food Safety 2018;8(4):204-14.

[5] Singh U, Dwivedi C, Kulsum U, et al. Phytochemistry and medicinal uses of moringa oleifera: an overview. Journal of Drug Delivery and Therapeutics 2017;7(6):104-16.

[6] Hamza TA, Azmach NN. The miraculous moringa trees: From nutritional and medicinal point of views in tropical regions. Journal of Medicinal Plants Studies 2017;5(4):151-62.

[7] El-Sohaimy SA, Hamad GM, Mohamed SE, et al. Biochemical and functional properties of Moringa oleifera leaves and their potential as a functional food. Global Advanced Research Journal of Agricultural Science 2015;4(4):188-99.

[8] Gopalakrishnan L, Doriya K, Kumar DS. Moringa oleifera: a review on nutritive importance and its medicinal application. Food Science and Human Wellness 2016;5(2):49-56.

[9] Oyeyinka AT, Oyeyinka SA. Moringa oleifera as a food fortificant: Recent trends and prospects. Journal of the Saudi Society of Agricultural Sciences 2018;17(2):127-36.

[10] Fitriana WD, Ersam T, Shimizu K, et al. Antioxidant activity of Moringa oleifera extracts. Indonesian Journal of Chemistry 2016;16(3):297-301.

[11] Saini RK, Sivanesan I, Keum YS. Phytochemicals of Moringa oleifera: a review of their nutritional, therapeutic and industrial significance. 3 Biotech 2016;6(2):203.

[12] Bhattacharya A, Tiwari P, Sahu PK, et al. A review of the phytochemical and pharmacological characteristics of
Moringa oleifera. J Pharm Bioallied Sci 2018;10(4):18191.

[13] Abd Karim NA, Ibrahim MD, Kntayya SB, et al. Moringa oleifera Lam: targeting chemoprevention. Asian Pac J Cancer Prev 2016;17(8):3675-86.

[14] Said-Al Ahl HAH, Hikal WM, Mahmoud AA. Biological Activity of Moringa peregrina: a review. American Journal of Food Science and Health 2017;3(4):83-7.

[15] Kumar G, Giri A, Arya R, et al. Multifaceted applications of different parts of Moringa species: review of present status and future potentials. International Journal of Chemical Studies 2019;7(2):835-42.

[16] Prabakaran M, Kim SH, Sasireka A, et al. Polyphenol composition and antimicrobial activity of various solvent extracts from different plant parts of Moringa oleifera. Food Bioscience 2018;26:23-9.

[17] Wambebe C. African Indigenous Medical Knowledge and Human Health. $1^{\text {st }}$ edn. Moringa: the miracle plant. CRC Press 2018:165-92.

[18] Jaja-Chimedza A, Graf BL, Simmler C, et al. Biochemical characterization and anti-inflammatory properties of an isothiocyanate-enriched moringa (Moringa oleifera) seed extract. PLoS One 2017;12(8):e0182658.

[19] Liyongo CI, Bongo GN, Ashande CM, et al. An updated review on the bioactivities and phytochemistry of the nutraceutical plant moringa oleifera Lam (Moringaceae) as valuable phytomedicine of multi-purpose. Discovery Phytomedicine 2018;5(4):52-63.

[20] Chaudhary K, Chaurasia S. Neutraceutical properties of Moringa oleifera: a review. Eur J Pharm Med Res 2017;4(4):646-55.

[21] Anwar F, Latif S, Ashraf M, et al. Moringa oleifera: a food plant with multiple medicinal uses. Phytother Res 2007;21(1):17-25.

[22] Nazim K, Sun MC, Neergheen VS. Perceptions and practices on the use of Moringa oleifera Lam: a qualitative study amongst elderly mauritians. Journal of Complementary and Alternative Medical Research 2017;2(2):1-3.

[23] Koul B, Chase N. Moringa oleifera Lam.: panacea to several maladies. J Chem Pharmaceut Res 2015;7(6):687-707.

[24] Sujatha BK, Patel P. Moringa oleifera-nature's gold. Imperial Journal of Interdisciplinary Research 2017;3(5):1175-9.

[25] Vergara-Jimenez M, Almatrafi M, Fernandez ML. Bioactive components in Moringa oleifera leaves protect against chronic disease. Antioxidants 2017;6(4):91.

[26] Tiloke C, Phulukdaree A, Anand K, et al. Moringa oleifera gold nanoparticles modulate oncogenes, tumor suppressor genes and caspase-9 splice variants in A549 cells. J Cell Biochem 2016;117(10):2302-14.

[27] Wang C, Wu R, Sargsyan D, et al. CpG methyl-seq and RNAseq epigenomic and transcriptomic studies on the preventive effects of Moringa isothiocyanate in mouse epidermal JB6 cells induced by the tumor promoter TPA. J Nutr Biochem 2019;68:69-78.

[28] Kraiphet S, Butryee C, Rungsipipat A, et al. Apoptosis induced by Moringa oleifera Lam. pod in mouse colon carcinoma model. Comparative Clinical Pathology 2018;27(1):21-30.

[29] Olayinka LM, Clement OB. Protective role of Moringa oleifera leaf-based diet on protein-energy malnutrition 
induced skeletal muscle degeneration. Int J Sci Rep 2017;3(2):54-62.

[30] Kapoor LD. Handbook of ayurvedic medicinal plants: herbal reference library. Routledge 2017.

[31] Kamath N, Swaminathan R, Desai N. Antibacterial activity of Indian medicinal plant Moringa oleifera against MRSA and Klebsiella Spp.(ESBL) which are commonly isolated bacteria in hospital environments. International Journal of Applied Research 2016;2(8):515-7.

[32] Onsare JG, Arora DS. Antibiofilm potential of flavonoids extracted from Moringa oleifera seed coat against staphylococcus aureus, pseudomonas aeruginosa and Candida albicans. J Appl Microbiol 2015;118(2):313-25.

[33] Moura MC, Trentin DS, Napoleão TH, et al. Multi-effect of the water-soluble Moringa oleifera lectin against serratia marcescens and bacillus sp.: antibacterial, antibiofilm and anti-adhesive properties. J Appl Microbiol 2017;123(4):861-74.

[34] Lee JH, Kim YG, Park JG, et al. Supercritical fluid extracts of Moringa oleifera and their unsaturated fatty acid components inhibit biofilm formation by Staphylococcus aureus. Food Control 2017;80:74-82.

[35] Brilhante RSN, Sales JA, Pereira VS, et al. Research advances on the multiple uses of Moringa oleifera: a sustainable alternative for socially neglected population. Asian Pac J Trop Med 2017;10(7):621-30.

[36] Delelegn A, Sahile S, Husen A. Water purification and antibacterial efficacy of Moringa oleifera Lam. Agric \& Food Secur 2018;7(1):25.

[37] Elgamily H, Moussa A, Elboraey A, et al. Microbiological assessment of Moringa oleifera extracts and its incorporation in novel dental remedies against some oral pathogens. Open Access Maced J Med Sci 2016;4(4):58590.
[38] Carranza JB, Molina PG, Ortañez JJR, et al. Flavonoids, alkaloids and tannins of three varieties of horse radish (Moringa oleifera Lam.) extracts: potential components of toothpastes. International Scholars Conference Proceeding 2017;5(1):30-3.

[39] Jose M, Sharma BB, Shantaram M, et al. Ethnomedicinal herbs used in oral health and hygiene in coastal Dakshina Kannada. Journal of Oral Health and Community Dentistry 2011;5(3):119-23.

[40] Khalaf EAS, Nagib AM, Amin LEM, et al. Biological effects of topical application of moringa oleifera extract versus fluoride on uremic patients extracted teeth. Int J Adv Res 2016;4(9):1513-20.

[41] Rao PK, Rao DB, Kiran C, et al. In vitro antibacterial activity of Moringa oleifera against dental plaque bacteria. Journal of Pharmacy Research 2011;4(3):695-7.

[42] Alsaraf KM, Abd ST, Husain NS. An antimicrobial activity of moringa oleifera extract in comparison to chlorhexidene gluconate. (In vitro study). Journal of Baghdad College of Dentistry 2016;28(1):183-7.

[43] Rostiny R, Djulaeha E, Hendrijantini N, et al. The effect of combined Moringa oleifera and demineralized freezedried bovine bone xenograft on the amount of osteoblast and osteoclast in the healing of tooth extraction socket of Cavia cobaya. Dental Journal (Majalah Kedokteran Gigi) 2016;49(1):37-42.

[44] Yadav NR, Garla BK, Reddy VK, et al. Antimicrobial effect of honey on streptococcus mutans of dental plaque. Journal of Oral Health \& Community Dentistry 2014;8(2):72-5.

[45] Jain M, Chahar P, Jain V, et al. Role of quercus infectoria in health and oral health-a review. International Journal of Green Pharmacy 2019;13(3)180-5. 